\title{
A Note for Indonesia's Border Diplomacy in Tanjung Datu, West Kalimantan
}

\author{
Iva Rachmawati \\ Department of International Relations, Universitas Pembangunan "Veteran" Yogyakarta, Indonesia \\ iva.rachma@gmail.com

\section{Machya Astuti Dewi} \\ Department of International Relations, Universitas Pembangunan "Veteran" Yogyakarta, Indonesia \\ Machdewi@yahoo.com \\ Submitted: 1 November 2019; Revised: 20 June 2020; Accepted: 22 July 2020
}

\begin{abstract}
Abstrak
Artikel ini bertujuan untuk mengusulkan perombakan mendasar pemahaman diplomasi perbatasan Indonesia, yang sejauh ini masih berpusat pada negara dan hanya memprioritaskan peran pemerintah pusat. Meski termasuk dalam ranah isu high-politics, diplomasi perbatasan tidak dapat lagi dipraktikkan secara elitis. Mengacu pada beberapa masalah yang muncul di tingkat praktis dan akademis, sudah saatnya diplomasi perbatasan Indonesia memperluas diplomasi dengan mempertimbangkan aktor penting lainnya, yaitu aktor subnasional dan aktor non-negara. Tidak hanya di tingkat provinsi, tetapi aktor sub-nasional ke tingkat terendah di wilayah perbatasan juga memiliki kontribusi yang signifikan terhadap diplomasi perbatasan Indonesia, serta aktor non-negara dari akademisi. Artikel ini merupakan hasil penelitian berdasarkan metodologi kualitatif menggunakan wawancara mendalam dan studi dokumentasi. Penelitian ini menemukan banyak catatan penting, termasuk pertama, kesimpangsiuran informasi dalam masalah Tanjung Datu di Camar Bulan dan Gosong Niger telah merusak hubungan bilateral antara Indonesia dan Malaysia. Kedua, independensi dalam praktik hubungan antara dua komunitas antar negara menunjukkan bahwa aktor subnasional memiliki pengaruh vital terhadap hubungan bilateral Indonesia-Malaysia. Kata Kunci: diplomasi perbatasan, aktor subnasional, aktor non-negara, Tanjung Datu.
\end{abstract}

\begin{abstract}
This article aims to propose a fundamental overhaul of the understanding of Indonesia's border diplomacy, which has so far state-centric and only prioritizes the role of the central government. Despite being in the high politics issue, border diplomacy can no longer elitist practiced. Referring to several problems that arise at the practical and academic level, Indonesia's border diplomacy is the time to expand diplomacy by considering other important actors, namely subnational actors and non-state actors. Not only at the provincial level, but sub-national actors to the lowest level in the border region also have a significant contribution to Indonesia's border diplomacy, as well as non-state actors from academia. This article is the result of research based on a qualitative methodology using Personal Communication withs and documentation studies. The research discovered many essential notes, including firstly, the confusion of information in the Tanjung Datu issue in both Camar Bulan and Gosong Niger has harmed the bilateral relations between Indonesia and Malaysia. Second, independence in the practice of relations between two communities between countries showed that subnational actors have a vital influence on Indonesia-Malaysia bilateral relations. Keywords: border diplomacy, subnational actors, non-state actors, Tanjung Datu.
\end{abstract}

\section{INTRODUCTION}

The Tanjung Datu border is the Indonesia-Malaysia border at the northern end of West Kalimantan. This border still leaves a problem with the emergence of several issues of the annexation of Indonesian territory by Malaysia some time ago. Both the occupation of areas in Camar Bulan and Gosong Niger have led to tensions in the relations between Indonesia and Malaysia. the relations between Indonesia and Malaysia. Camar Bulan became a wedge for relations between Indonesia and Malaysia when TB Hasanudin (a member of the House of Representatives of RI Commission 1) stated that Malaysia had annexed Indonesian territory. This statement became a relatively hot issue between Indonesia and Malaysia in 2011. Hasanudin said that Malaysia had 
taken 1400 hectares of Indonesian area in Camar Bulan and $80,000 \mathrm{~m} 2$ in Tanjung Datu (Gultom, 2001). The Governor of West Kalimantan, Cornelis, also stated that 1440 hectares of Indonesian territory had entered the land of Malaysia because Malaysia ignored the area under the peg number A88-A156 (this article would be called the Camar Bulan enclave), which belonged to Paloh Regency. Cornelis acknowledged that he had received information that the National Survey and Mapping Coordinating Board (Bakosurtanal) had to put Camar Bulan into Malaysian territory. Cornelis also urged that the takeover of this area was not signed because it was very detrimental to Indonesia, especially the West Kalimantan administrative area (Suara Pembaharuan, 2011). The issue of the taking over of the Camar Bulan pushed some residents to urge the government to protest against the Malaysian government.

Meanwhile, the issue of Gosong Niger emerged in 2005, beginning with a report from Indonesian fishers that the Indonesian-owned lighthouse, which was a Dutch heritage, had been given a wire fence by the Malaysian side. Another issue that has emerged in this area is the issue of developing the Tanjung Datu area as a tourism attraction by Malaysia (Viva, 2011). The Indonesian-Malaysia conflict also culminated when Malaysia established a lighthouse in Indonesian waters, and even many fishers were evicted from the area where they used to catch fish in 2014. The Malaysia Navy (Polisi Diraja Malaysia) blocked the ship of Maritime and Fisheries Office of West Kalimantan Province, who surveyed the lighthouse. The Malaysia Navy only allowed them to see the Gosong Niger area from a tower built during the Dutch colonial period. The TNI immediately sent KRI Sutedi Senoputra (SSA) and a transport plane consisting of Regional Military Command and Indonesia Navy to stop the activity since the action was illegal (Sucipto, 2014).

Border disputes in Camar Bulan and Tanjung Datu (from now on referred to as Tanjung Limited with the contribution of the agreement) show that overcoming borders cannot be released only on the boundary line. The Tanjung Datu border has reached an agreement in 1976 and 1978. However, it turns out that the border agreement made by the government on conflicts between countries was not agreed upon. Border diplomacy to resolve differences in interests at the border. Border diplomacy depends on other actors, especially sub-national actors. They are in the border region and other non-state actors as supporting actors in the protection of the boundary between state borders. This article was published to approve the practice of conducting border diplomacy in Indonesia. This article is the result of research on the practice of border diplomacy by subnational and non-state actors in the Tanjung Datu border region. These actors can have a significant relationship in the implementation of border diplomacy practices.

\section{LITERATURE REVIEW}

Indonesian Border Diplomacy is rarely studied. The primary reference to the development of the idea of Indonesian border diplomacy, in general, moved from two concepts, namely diplomacy and borders. Djalal (2012), Andika (2017), Oegroseno (2012), Rachmawati \& Fauzan (2012), Anggita (2014), and Meilisa (2018) began an explanation of border diplomacy by referring to the traditional conception of state-centric diplomacy. The state-centric view stems from an understanding that border issues are a matter of security. This understanding brings such an issue to the realm of high politics, which can only be managed by the state or central government. Political geographer, John Agnew, criticized this issue by hearing it as a 'territorial trap', namely how state-centered thinking is the dividing line between inside and outside. Territorial traps rely on three assumptions taken for granted. First, the sovereignty, security, and political life of the modern state require limited territorial space. Second, there is a fundamental conflict between the internal and external affairs of a country. Third, the territorial state functions as a geographical container for the modern society where state boundaries coincide with boundaries formed by political and social processes. This way of thinking shows that the world consists of mutually exclusive and restricted areas with their own collective identities. Thus, the main contours of society are viewed as coinciding with state borders (Paasi, 2009). 
In the practice of Indonesian border diplomacy, this approach was seen when the government formed the KK Sosek Malindo, which was placed under the Ministry of Defense. Although KK Sosek Malindo intended to boost the non-political cooperation between two countries, the results were less optimal (Rachmawati \& Fauzan, 2012). Wirawan's research (2019) also shows that the Malindo Socio-Economic CoW was unable to meet regional needs; in this case, Sambas Regency. Wirawan stated that one of the causes of the Malindo Socio-Economic Coordination slow was the difference in interpretation of development in the border area between agencies. For example, three districts in West Kalimantan (Sanggau, Sambas, Kapuas Hulu) proposed access to be able to buy electricity from Malaysia due to the limited electricity supply from the State Electricity Company. However, this proposal was rejected by the Indonesian Military Forces because they thought it could trigger Indonesia's dependence on Malaysia. From Wirawan's research, elite actors personally have a significant contribution to the development in border areas and bilateral relations.

Meanwhile, the liberal approach offers an understanding that boundaries derive their normative weight from the consent of individuals living within the boundary (Bennet, 1996). States are not the only political actors who draw the boundary. The border would be very dynamic, depending on the interaction and perception of the border resident. Their ease of activity and prosperity also determine the determination of the border. Thus, the primary function of the state borders is to ensure contacts between neighboring countries and facilitate their interactions (Kireev, 2015). This liberal view is an essential note for this article to understand border diplomacy. The issue of borders is not only a question of boundaries but also all political, social, and economic problems at the border. Borders are no longer separating edges, but boundaries to connect. In reality, those living on the border are not socially and culturally different people. They must be politically separated because of the borders dividing the territories they live in. This view is a significant contribution to understanding border diplomacy in this article, which offers the role of actors outside the state or central government.
Diplomacy itself is an art in promoting the interests of a country through negotiations in peaceful ways concerning other countries (Roy, 1999). However, some argue that in the context of organizing national interests against other countries, diplomacy is not only about how national interests are organized or pursued, but it also talks about how the policy is proposed. Brian White (in Baylis \& Smith, 2001) confirms it by saying that diplomacy is a government activity that is not only a particular foreign policy-making but also an entire policy-making as well as its implementation.

Concerning the issue carried out in border diplomacy, namely the border, in this case, the edge is understood as a line dividing the territories where the state can exercise its full territorial sovereignty. Border not only separates the area owned by different communities but also ensures the security of each area concerned (Caflish, 2000). The same thing was stated by Starke (1972) that the border is one of the essential manifestations in a country and not only as an imaginary line on the earth's surface but a line separating one region from another. Moreover, Rachmawati \& Fauzan (2012) define border diplomacy as an effort made by the government of a country to guarantee its sovereignty. Government efforts in the context of conducting border diplomacy certainly cannot only be seen in terms of law and security but also of socio-economic aspects. In contrast, Fatmasari (2012) emphasizes the role of the military in defense diplomacy to secure the country's border area. Oegroseno (2006) points out that border issues are either a matter of boundary or the management of border areas. Border diplomacy is the implementation of foreign policy in the context of handling border issues that cover borders of land and sea states and managing various border issues with an international dimension. Referring to the understanding of border diplomacy, it appears that the country still dominates the implementation of border diplomacy.

However, an interesting note on border diplomacy was stated by Henrikson (2000), explaining that border diplomacy is an effort of both the state and non-state actors to maintain harmonious relations between bordering states. Border diplomacy is only possible 
through what he calls bon voisinage diplomacy or good neighborhood diplomacy. First, every country must consciously recognize that there are important issues within the country's borders. Thus, each state gives full attention to the problem of national borders. Second, every country must have organized management and clear laws regarding national boundaries. That way, there is a well-managed relationship regarding the country's borders through these institutions. Third, in line with what Friedrich Ratzel mentioned, that national borders are the "peripheral organs" of a nation; therefore, the friction of interests regarding state borders should be avoided through joint management. The bilateral or multilateral or cross-border cooperation systems could effectively strengthen bilateral cross-border relations in the world (Henrikson, 2000).

An important note from Henrikson (2000) is that diplomacy focusing on borders must coordinate central and peripheral interests in managing national borders. In other words, both the central and peripheral governments must be able to find adjustments in border management related to mutual interests with neighboring countries. The idea to involve subnational actors came from Duchacek as an academic who proposed the involvement of paradiplomacy in the implementation of border diplomacy, namely the participation of regional governments in international relations, through the establishment of formal and informal, bilateral or multilateral contacts with external parties (Duchacek, 1990). The idea of open communication has provided significant support for them to contribute to the relations between countries. The privilege of making an agreement and cooperation without the presence of a central government is a recognition of the subnational actors' influence in the relationship between countries (Bradshaw, 1998; Jordan \& Khanna, 1995). The number of agreements and policies that have become part of local government jurisdiction states their level of autonomy regarding the central government (Martínez, 2018). Cornago noted that they have an essential role in political and security issues between countries. As such, they not only make significant contributions to social and economic problems (Cornago, 2009; Sergounin, 1999;
Aranda \& Salinas 2017).

In addition to subnational actors, diplomacy has arrived at the recognition of the influence of non-state actors. Note La Porte (2012) states that public support from within the state (domestic actors) is essential in diplomacy because globalization has given non-state actors an efficacy in influencing state considerations in conducting relations between countries. Non-state actors are legitimate and have efficacy when they can get public support and achieve their goals. More specifically, Chitty (2011) mentions that domestic actors influencing diplomacy are civil society, non-profit organizations or institutions, and the media. The critical position of local actors in diplomacy encouraged Huijgh (2016) to suggest that public diplomacy would combining (1) of so called old and new practices; (2) of the spheres of at home and abroad in public diplomacy; (3) of public diplomacy into broader (inter) nastional policy making and conduct, and; (4) of hard and soft power. The second argument means that while public diplomacy has long been associated with only foreign publics, it should also include activities directed towards domestic citizens. Their understanding and support of a government's policy and their efforts to reach out to peers abroad are crucial to a country's (inter)national credibility and efficiency. In international policy-making and conduct nowadays, the "inter" matters as much as the "national," with the roles of domestic citizens being increasingly acknowledged. The emergence of actors other than the state and central government in developing diplomacy posture triggers the need to discuss the role of both subnational and non-state actors in Indonesian border diplomacy.

\section{RESEARCH METHOD}

This article is the result of research conducted at the Indonesian border in the Camar Bulan and Gosong Niger hamlets in Temajok Village, Paloh District, West Kalimantan Province, Indonesia using the direct survey and in-depth interview methods with several relevant respondents. They were local officer in Temajuk Hamlet, Herlin (the head of Camar Bulan Village), Ibrahim (the locall Officer of Camar Bulan Village) and Harun (the 
head of Maludin Village). We also interviewed Usman (the former of Paloh Sub-District Head), Manto Saidi (Former Head of Sambas Local Border Management Agency) Uray Willy (Head of Economic Affairs and Natural Resources Secretary of Sambas Regency) Henry (Head of Military Border Officer) and Rahmad (Resident). To complete the data analysis, the researchers used documentation studies. The data obtained were analyzed to the extent to which the subnational actors and other non-state actors contribute to relations between countries in the border region, especially in Tanjung Datu. The analysis covered their understanding of border management, perceptions, and actions toward conflict or border issues. The impact of subnational and non-state actors' opinions and activities will be essential in putting their role in border diplomacy, which has so far only been understood as diplomacy organized by the state or central government.

\section{RESULT AND ANALYSIS}

\section{CAMAR BULAN AND GOSONG NIGER IN TANJUNG DATU}

The issue that has arisen over Tanjung Datu is an area located in Temajuk Village, Paloh District, Sambas Regency, Povisi West Kalimantan. The land border dispute occurred in the Camar Bulan enclave area, an area resembling a niche that jutted toward the territory of Indonesia having an area of 1,499 ha with a peg boundary no. A88-A156. The area is uninhabited and is a Malaysian protected forest area. Being a dispute because for Indonesia, the area was still part of the 10 Outstanding Border Dispute until the MoU in 2011, which again referred to the $1978 \mathrm{MoU}$ where the enclave area was Malaysian territory. Conversely, the second Tanjung Datu issue is Gosong Niger, which is a sea border area to the north of Temajuk Village. Gosong Niger is an essential issue for the Indonesian border region of Malaysia because, in this area, conflicts between Indonesia and Malaysia often occur. The difference in interpretation of the withdrawal of boundary lines on land (Tanjung Datu) can affect the borderline in the Natuna Sea. Although it is clear the agreement between the two countries on this matter, in practice, the sea border does not provide enough physical boundaries to help those who are active in the region.

The mention of the Camar Bulan area as Tanjung Datu is not entirely wrong (though the local community does not know it), because it refers to the London Treaty. The area is part of the Indonesian-Malaysian border at Tanjung Datu. In the treaty, there was no mention of Camar Bulan, nor did Gosong Niger. The convention only used the name Tanjung Datu as the boundary in West Kalimantan.

"The boundary starts on the east coast at latitude $4^{\circ}$ $10^{\prime} \mathrm{N}$. After the Sebatik Island was divided, the border crosses the waters between the island and the mainland in a curved line following the median of the Tamboe and Sikapal channels to the Sikapal range, forming the water divide between the Serudong and Simengaris rivers. The water divide is generally followed westward to $116^{\circ} 49.9^{\prime}$ E. where the Seboeda River is crossed. Mounting the minor water divides, the boundary continues westward to $116^{\circ} 42.3^{\prime}$ E. where the Agisan River, a tributary of the Seboekoe, is also intersected. In like manner, the boundary meanders westward to $116^{\circ} 26.2^{\prime} \mathrm{E}$. where the Pantjiangan River, an upper course of the Sembakoeng, is also crossed. ......The boundary, where it follows a stream, has been defined as the right bank of the specific stream. Pillars, either of wood or concrete, mark the major turning points. The stretch along the boundary measures approximately 19.75 miles. On the peak of Api mountain, the boundary returns to the water divide for an additional 78 miles northwestward and then northward to the South Cina Sea at Tandjung Datu." (The Geographer, 7-8).

Thus, the Tanjung Datu problem currently covers two border issues, namely the Camar Bulan enclave and Gosong Niger, both of which are located at the tip of West Kalimantan. Referring to the London Treaty, Gosong Niger is excluded as agreed because Niger Gosong is not situated on the land border. However, the development of the conflict that occurred in the area in question, the Gosong Niger, cannot be ignored as part of the border issue at Tanjung Datu. Often leading to 
the border issue at Tanjung Datu. Often leading to miscommunication, the remark must be made manifest, given the progress of the settlement between Indonesia and Malaysia that continues to be more detailed in certain regions. This treaty still leaves $10 \mathrm{OBP}$ for Indonesia (The House of Representatives has not yet ratified the $2011 \mathrm{MoU}$ about Camar Bulan problem) and 9 OBP for Malaysia (In Malaysia's perception, the Camar Bulan problem has already completed). This kind of ambiguity often results in errors and inaccurate information for the general public who do not understand the border issues in-depth and results in unnecessary negative sentiment impacting Indonesia-Malaysia bilateral relations.

\section{CAMAR BULAN BORDER DIPLOMACY AND SUB-NATIONAL ACTORS}

As part of the London Treaty of 20 June 1891, signed on 28 September 1915, Camar Bulan had exceeded the number of post-independence demarcation agreements. Referring to the Army Topographic Direktorat, border settlement trips in West Kalimantan have been carried out from 1973 to 2000 by producing 20,311 pillars, including in the Tanjung Datu area. The settlement of the border has gone through 3 stages; namely, the first is the process of surveying the demarcation area determination in 1973, where it was agreed by the two countries to use an agreement between Britain and the Netherlands. The next stage is the two countries conducted a joint survey from 1973-1976 utilizing the watershed method that succeeded in agreeing on several border markers and building many pillars (in Article 1 of the Memorandum of Understanding of Demarcation Survey of the International Boundary between the Government of Indonesia and the Government of Malaysia 1976), namely:
a. Pillar I: Point A 98 to A 156 Point A 231 to C 1 Point $\mathrm{G}$ to $\mathrm{H} 1$
b. Pillar II: Point D 001 to D 186 Point D 186 to D 300

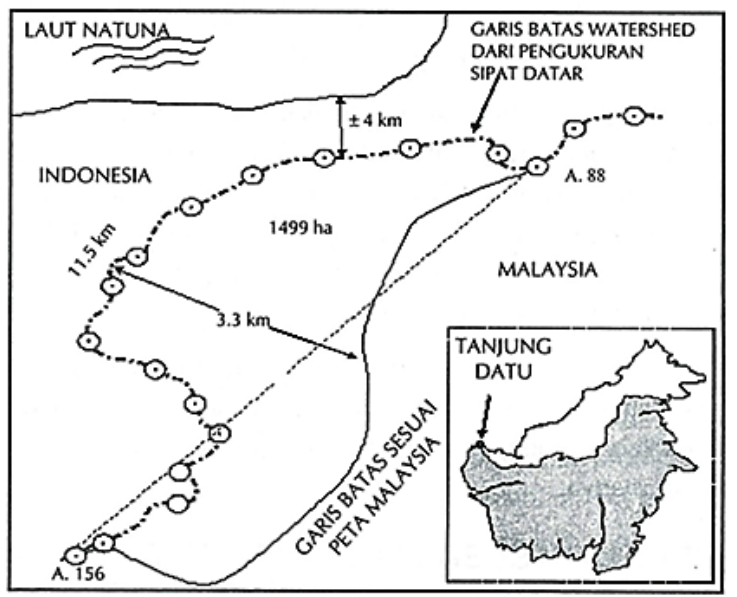

Figure 1. Camar Bulan Source (Hadiwijoyo, 2011)

Regarding the Tanjung Datu area, the Indonesia Malaysia meeting was held in Kinabalu to agree on the Tanjung Datu border on stakes number A1-A98 in 1976. The second $\mathrm{MoU}$ was held in the same year in Yogyakarta to decide on pegs A156 - A 231, while the third MoU agreed on pegs A98-A156 (the Camar Bulan Enclave was recorded at the A88-A156 peg) in Semarang in 1978.

Unfortunately, after surveyed in 1973, 1976, and 1978, the survey team just discovered a problem when holding the follow-up survey in 2001. Problems arise due to the borderline that protrudes into Indonesia to benefit the Malaysian region, and by watershed methods, they could not find the pegs. The result of the 2001 survey team's review was the reason why Indonesia claims that the $1976 \mathrm{MoU}$ was a mistake and ask for the review for the MoU. The renegotiations were carried out in 2011 on problems arising in 2001, and the result was the borderlines between two countries had to referring the 1978 MoU.

The state has started border diplomacy over the Indonesian border state of Malaysia in the Camar Bulan enclave since 1976 until the last attempt by the Indonesian government in 2011. Unfortunately, all border diplomacy performance is still dominated by the state (central government), which resulted in the emergence of border issues in the public sphere. This condition then caused relations between the two countries to deteriorate. The lack of public understanding of the Camar Bulan problem is partly due to limited information about it. condition then caused 
lack of public understanding of the Camar Bulan problem is partly due to limited information about it. Even if they obtain information about the Camar Bulan conflict, that information tends to be unclear or even wrong. Meanwhile, socialization regarding the results of the bilateral agreement was also rarely carried out either by the Ministry of Foreign Affairs, the National Border Management Agency, or KK Sosek Malindo as an organization specializing in discussing socio-economic issues in the border region. The last institution has even been working since 1983 but not enough to make a significant contribution to the management of border areas.

This information limitation is found not only among the border residents but also among the local political elite and academics. The residents had no information on how to manage the conflicted area and even the agreement between Malaysia and Indonesia. Most of them acknowledge that they do not know the 2011 agreement deciding the Camar Bulan enclave status. They also noticed that the Camar Bulan enclave in Malaysia protected the forest (Herlin, Ibrahim, and Harun, Personal Communication, March 2019).

However, the lack of involvement of subnational actors in the management of border areas resulted in the emergence of a misunderstanding about the management of border areas. It is found through interviews conducted with subnational actors who believe that the area occupied and or managed is one way to control the area.

"Many of our people there. Why? Yes, because we have to master it. It means that we want to manage it, which cannot be destroyed. Our population is looking for food, human rights. If it is damaged, especially for business or for sale, that is not allowed. For gardening, staying there does not matter." (Usman, Personal Communication, March 2019).

An attempt to mobilize the residents to plant crops illegally was recognized by the local elite, who believed that it should be done. In an interview with the former Head of Sambas Local Border Management Agency, it was found that there was no awareness of the management of the disputed area among the local officials.
"...What I regret is the productive land that is cultivated...I provoked my community in the hall of the sub-district office to work for productive land there. At that time, the regent responded to my provocation by providing productive plant seeds. Finally, from 2012-2014, the local community planted there, but we told them that at any time, this land could be released from our hands because this land was still in dispute. We gave such kind of understanding. Then when we have to release it, it is a pity that they like productive land." (Manto Saidi, Personal Communication, March 2019).

Even at the lowest level, residents get reinforcement to enter the conflict area from the state apparatus. It was discovered during an interview with a member of Group 32 who carried out illegal planting in the Camar Bulan enclave from 2008 to 2017. He claimed to have obtained permission from the local government and military border commanders at the time.

"...Because it was the first time for me to hitch in a ride and then there was Danton, Mr. Saiful from Jogja, so I coordinated with him, he said, ow, it is still 1.3 kilometers. Then is it fine if I build a house...ow, it is no problem. Then I build it." (Rahmad, Personal Communication, March 2019).

The inaccurate views and policies arose solely because of the lack of socialization on the management of border areas and the negotiations' results, especially the 2011 negotiations, which finally eliminated the 10th OBP (Indonesian version). Encouragement to occupy the conflicted land arises because subnational actors feel neglected in managing border areas (Manto Saidi, Herlin, Ibrahim and Harus, Personal Communication, March 2019). On the contrary, when the Camar Bulan problem was explained, and the $2011 \mathrm{MoU}$ was socialized, residents who occupied the conflict area or known as group 31, were willing to leave the area. They left the area in 2017 after the Sarawak government asked them to leave, and the Sambas government provided clear information and subsidies.

However, they have an entirely positive contribution in managing bilateral relations at the lowest level. Social problems sometimes colour problems at the border. 
Marriage between residents of Indonesia and Malaysia is not always in good condition, as well as sports competition between residents. These social issues contribute to the border issues, which are not merely about demarcation or national borders. However, both social and economic problems are resolved at lower levels. In an interview conducted with several regional officials, they stated that many things were quite settled at the lower level. After all, if it were resolved at the national level, it would be complicated because it had involved the national ego. Personal relations between village heads in Indonesia and Malaysia become a means to resolve problems that occur between countries.

"...and it can be resolved with social diplomacy, not official diplomacy, it is grassroots diplomacy. It means that there is a personality relationship between the village head. There is a village chief there, there is a village chief here, there is a village head there, there is a village head here, we build good relationships and communication so that the problems of minor crimes...yes, even though they are included in the crime, yes, and have violated international law, but can be resolved without having to go through official or legal ways. Because if they have entered the formal legal way, there will be prestige, right." (Uray Willy, Personal Communication, March 2019).

Efforts to maintain good relations between local officials are also carried out regularly through informal visits or what is commonly called muhibah. Muhibah maintains good relationships that already exist and becomes their way to solve problems arising. Usman delivered this statement in the Telok Keramat sub-district, serving as the Paloh sub-district, an area that directly borders Kampong Telok Melano in Sewarak, Malaysia.

"To eradicate these conflicts, I conducted muhibah with Tumenggung, the immigrants, including the TNI, basically goodwill. For Tanjung Datu, I carried out the muhibah with him in Melano, and I went there with a group of people. There was no problem when I did it there. When I was in Sajingan, I had performed it with a group of people from the regency. Thus, it was somewhat safe. In my day, it was safe because I opened communication with each other, so there was no need to be tense. Therefore, everything looked safe and calm. If everything mobilizes the security forces, of course, our society will be afraid. If so, they will begin to consider the area unsafe. As in the case of Aceh and Papua, where there is no comfort for society." (Usman, Personal Communication, March 2019).

The influence of subnational actors on citizens' behavior and their role in managing conflict resolution at the border becomes significant in border diplomacy. They can become the leading think tank of the state or central government in maintaining state borders and harmony through cooperation. As well as the subnational actors, academic groups have a significant influence on border diplomacy, particularly on policy-making.

Academic groups have considerable potential in influencing policy-making, through communication and networking (Muluk \& Winoto, 2018) or the involvement of academics in policy-making and controlling policy outcomes (Ion et al., 2019). Himmrich (n.d) acknowledged that academics have limited access to policy-making. They must compete with government think tanks or private research companies. The limited access results in misinformation that confuses the ground. For example, inappropriate information shared by Mursito (2012) that "... The residents in the Tanjung Datu OBP are residents of Temajuk Village with 493 families and an area of approximately $4,750 \mathrm{~km} 2$ (total population of approximately 1,883 inhabitants." This error was even conveyed by an Indonesian Ministry of Defense spokesman Hartind Asrin, stating that "The residents residing in the Tanjung Datu OBP were Temajuk Village residents of 493 families and an area of approximately $4,750 \mathrm{~km} 2$ (total population of approximately 1,883 inhabitants) consisting of two hamlets namely Camar Bulan and Maludin". (Merdeka.com, 2011). This statement also certainly confuses Camar Bulan residents and local officials because Tanjung Datu is an uninhabited area. It is also a forest area located on a plateau at the end of West Kalimantan (Uray Willy, Personal Communication, 
March 2019). Himmrich (2016) suggests the need for an advocacy approach by academics and policy-makers. The epistemic community is an alternative in how academic groups can interact more closely with politicians. The development of collaboration between academic groups and the National Border Management Agency or Badan Nasional Pengelola Perbatasan (BNPP) has more or less opened up opportunities for the management of border areas in Indonesia. The Malindo Research Center and the Border Study Group, which were initiated by some researchers from several universities in Indonesia, began to gain access to border policy-making through dialogue with BNPP. Even though the results have not been good enough, the pilot to revise the traditional trading rules of the boundary line can be a positive sign for their cooperation (Rachmawati \& Dewi, 2020).

\section{GOSONG NIGER BODER DIPLOMACY AND NON STATE ACTORS}

The second issue covering the border in Tanjung Datu is the Gosong Niger problem. This problem arose when Malaysia began to carry out an effective occupation in the Gosong Niger region. The basis for Malaysia to claim this region is a one-sided map made by Malaysia in 1979. In this map, Malaysia has incorporated Gosong Niger into its territory by drawing a median baseline between the Malaysian baseline and the Indonesian waters bottom line. Niger Gosong called Permatang Naga (by Malaysia), is even included in the promotion and tourism activities around Melano Bay (Sarawak). Malaysia made this unilateral claim in early 2005. They argued that the establishment of Gosong Niger as a National Marine Park had been done a long time ago, and Gosong Niger was one of Malaysia's nature conservation areas. Sarawak people often use this area for fishing and also as one of the most popular tourist destinations (Jayanto, 2015; Arsana, 2006). Indeed, it is different from the calculation of Indonesia, which refers to UNCLOS, that Indonesia is an island nation, and Malaysia is a coastal country. As an archipelago, Indonesia is allowed to calculate the outer boundary of the territorial sea with a distance of 12 miles from the baseline, and the 200-mile line is the EEZ boundary. baseline, which shows that Indonesia has a stronger position than Malaysia.

Gosong Niger itself, based on geographical analysis, juridical analysis, and the results of plotting on the sea map number 420 published by the Oceanographic Service of the Navy and Bakorsurtanal, is a dune always submerged in water. It is not an island or a reef. In English, it is called sandbar or banks, or in Indonesian, it is called gosong. This mound is then known as Gosong Niger or Niger Banks.

The borderlines of the territorial waters of Indonesia and Malaysia in the Tanjung Datu and South China Sea areas have been regulated in the 1969 Indonesian and Malaysian Continental Boundary Agreement. Based on the Continental Shelf agreement dated October 27, 1969, and ratified by Presidential Decree No. 89 of 1969, there is an Eastern coordinate point (LCS 21-25) for the position of the Gosong Niger which divides the boundary line of the surface to the seabed between countries, where $2 / 3$ of the section blocks are in Indonesian territory or along approximately $5 \mathrm{~nm}(9 \mathrm{~km})$ entering Indonesia and about $0.8 \mathrm{~nm}(1.4 \mathrm{~km})$ belonging to Malaysia (See Figure

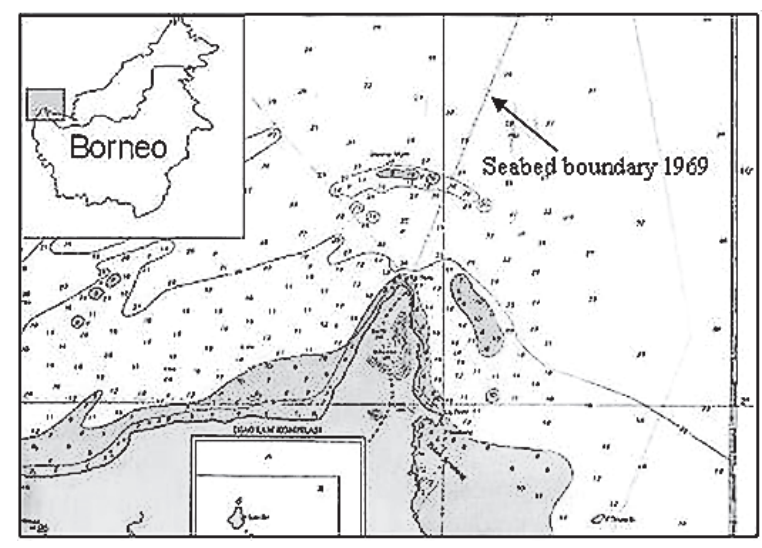

Figure 2. Gosong Niger (Arsana, 2006)

According to Arsana (2006), the division of the area is quite clear because $2 / 3$ of the seabed is on the Indonesian side. However, due to limited information, the activities of Malaysian navy vessels that patrol around Gosong Niger and do not allow Indonesian fishers to catch fish in the area are considered to have crossed national lines. Moreover, traditional fishers, in general, do not know that there are some areas under Indonesian 
sovereignty because they can see Malaysian ships parked in the area almost every day. As a result, Indonesian fishers do not have access to natural resources around Gosong Niger and think Malaysia has provoked it.

Indonesia itself has set the legal basis for sea borders through Law No. 6 of 1996 concerning Indonesian waters, which is an update of Law No.4 Prp of 1960. PP No.38 of 2002 concerning the Geographic Coordinate List of Indonesian Archipelagic Lines as the implementing law of the Act No. 6 of 1996. In connection with the 1969 Indonesian and Malaysian Continental Boundary Approval, the provisions of Government Regulation No.38 of 2002 become a supplement and renewal to include the position of its location in the list of base points and regional coordinate points areas that have not been registered in the preceding provisions. In the rules of PP No.38 of 2002, as a unilateral step from the Indonesian government toward the Gosong Niger boundary, it has been registered at the base point (TD) No. 35 which located at coordinates 02'05' 10" North Latitude and $109^{\circ}$ 38'43" East Longitude, determined based on the low water line.

The coordinate point on the coast of Tanjung Datu is vital for the Indonesian sea because it can be made into the existence of a base point and a reference point to attract the outermost demarcation that will pass or load the Gosong Niger territory within. Awareness of the importance of maintaining national borders encouraged Indonesia to build a new lighthouse to replace the Dutch lighthouse, which has been more than 128 years old and has not been functioning since 1978. In 2006, a lighthouse with modern equipment was rebuilt by the Directorate General of Sea Transportation as high as 43 meters and can reach as far as 20 nautical miles of sea $\mathrm{x}$ $1852 \mathrm{~m}$, at an altitude of 166.13 meters in the protected forest area of the slopes of Mount Datu. Besides, three floating flares were built on the base of the Niger Gosong Tanjung Datu waters region at a distance of 5.5 nautical miles from the mainland $(10.185 \mathrm{~km})$ covering an area of 50 ha. The Gosong Niger shallow area is physically submerged in seawater between 8 and 10 meters deep (Bureau of Communication and Public Information, 2015)
Malaysian activities in this area are very aggressive. In January 2011, a team led by KRI Teluk Sabang Implementing Officer, Captain Ujang Dharmadi, successfully landed and identified boundaries to the lighthouse on the border. Malaysia built its first flare as high as 10 meters in 1987 because it went out, a new flare was built again as high as 7 meters in 1990. This beacon was included in the International Intermediate Beacon List in 2004. At that time, the Ujang Dharmadi team managed to find the loss of the A1 peg until A3, which is the point of measurement for Indonesia's sea area. In the survey, the team also found that the Malaysian Measurement and Mapping Office had made its peg in Tanjung Datu. The stakes are made on top of a 6 meter high stone, about 100 meters away from Indonesia's A4 stakes. However, this new stake entered Indonesia's territory around 8 meters. According to Dharmadi, if this point is used as the base point of the line to measure the continental shelf, Indonesia's sea area will shrink (Kalbariana, 2011).

Instead of changing the peg, Malaysia built the $14 \mathrm{~m}$ tall lighthouse in the Tanjung Datu area in 2014. Nevertheless, it was immediately stopped because they recognized that it had exceeded the borderline. According to the head of the research center of Indonesia Military Forces headquarters, Mayjen Fuad Basya, Malaysia has built the lighthouse's foundation on the coordinate of 05'53" North Latitude and $109^{\circ} 38$ '37" East Latitude. The location is on the southwest water in the tip of Kalimantan Island. The point is on $900 \mathrm{~m}$ in front of STRP 1 peg, which is on the Paloh District area, Sambas Regency, West Kalimantan (Republika.co.id, 2019).

After receiving a report from the Indonesia Military Forces, the Ministry of Foreign Affairs immediately coordinated to hold a meeting of the Indonesian and Malaysian technical teams to discuss the continuation of the lighthouse construction case in Tanjung Datu. The meeting was considered the best option rather than a political settlement (Syahni, 2014). After the meeting, Malaysia immediately dismantled the lighthouse foundation built based on the technical agreement between the two countries. 
The determination of the sea boundary line is not only related to the boundaries between countries but also the implementation of state sovereignty. State sovereignty refers to the right to manage all-natural resources in it, both mineral and marine resources in the form of fish. Referring to the previous Sambas Regent, Burhanudin A. Rasyid, the location of Gosong Niger is indicated to contain natural wealth in the form of oil and gas (Palupi, 2007). The information about the mineral resources in Tanjung Datu also supported by the opinion of Usman, a former Paloh Sub-District Head, who stated that research on the potential of Gosong Niger has shown that the area has considerable iron ore potential. He also considered Malaysia to deliberately build a lighthouse and hold fishing boats, and thus it could control the sea north of Tanjung Datu (Usman, Personal Communication, March 2019).

Not much different from the Camar Bulan issue, the Gosong Niger issue is still a problem not too widely understood by several subnational actors at the lower level (villages). Malaysian patrols often prohibit Indonesian fishers from being in the Gosong Niger area. The fishers obeyed. After all, they did not know that Indonesia partly owned the area that they used to know as Pematang Naga or Beting Kepala Tanjung because almost every day, they saw Malaysian ships in the area (Rachmawati \& Dewi, 2019). On the one hand, the socialization of the sea boundary line has also never been well done. On the other hand, an understanding of Gosong Niger is also not always accurate, as Arsana stated that Gosong Niger is not an island.

"Yes, it was a small island affected by abrasion...(Gosong Niger) Quite large, I estimate it about five hectares. However, it has abrasion, and we have never done the research, yes, the research should be there for the benefit of defense. If it still appears as an island, not in a charred form, we are still safe from the border of Tanjung Datu...We lose the point to draw the line because of abrasion. I do not know if it is still possible to reclaim it". (Manto Saidi, Personal Communication, March 2019).

Inadequate management of border areas and limited information cause the management of border issues inaccurate. As adjoining countries, Indonesia and Malaysia have overlapping claims oversea areas, which is undoubtedly a vulnerable issue without the support of information transparency and common perceptions between central and subnational actors in local governments. Indonesia has included Temajuk Village in the National Strategic Area and WP-3-K (Ocean Spatial Planning) Zoning Plan. The province of West Kalimantan has also designated Gosong Niger and Tanjung Datu waters as conservation areas and other utilization zones, as well as KSNT in the context of the Home State.

Subnational actors need always to be included in border diplomacy efforts to minimize misunderstanding of the management of border areas and synchronize management of central and regional borders. In line with Henrikson (2000), diplomacy focusing on borders must coordinate central and peripheral interests in managing national borders. In other words, both the central and peripheral governments must be able to find adjustments in border management concerning shared interests. The problem of Camar Bulan beach abrasion, which continues to erode the Camar Moon beach until only 700 from the outer peg of the Camar Bulan enclave (Henry, Personal Communication, March 2019) resulted in great disappointment because it was not immediately responded to by the central government. Meanwhile, the attempt to occupy the Camar Bulan enclave is an alternative to maintain their increasingly narrow living space.

"So the OBP story is old and the information we have captured is not very clear. Camar Bulan is also located on the beach. At that time, we were afraid if an abrasion occurred on the beach. If there was an abrasion on the beach and it eroded the area to the outermost point, then it would be difficult. Tanjung Datu would also be lost. So, when I was still at the border, we had told the Ministry of Home Affairs that they had to make a breakwater safety project to avoid abrasion eroding the coast. However, it has not been realized until now." (Uray Willy, Personal Communication, April 2019). 
Rachmawati \& Fauzan (2012) noted the importance of collaboration between economic, social, and legal factors as the basis for the institutionalization of border diplomacy, as Henrikson (2000) marked the importance of institutionalization such as laws and precise mechanisms in cooperation between countries. However, the involvement of sub-national actors (Duchacek, 1990; Henrikson, 2000; Cornago, 2009; \& Martinez, 2018) has become unavoidable in border diplomacy. Academic groups as an essential part of the development of the discourse on the management of border areas as the main mouthpiece of public information is also a vital element for Indonesia's border diplomacy.

\section{CONCLUSION}

Indonesia's border diplomacy in Tanjung Datu is still experiencing limitations. Several issues that even often confuse relations between Malaysia and Indonesia are important indicators of how border diplomacy has been carried out. Several border diplomacies between Indonesia Malaysia related to the border in Tanjung Datu were held to complete the demarcation in Camar Bulan and Gosong Niger. Efforts to resolve this demarcation still leave obstacles up to 2011 because the House of Representatives has not ratified the $2011 \mathrm{MoU}$ stating that Malaysia owns the Camar Bulan enclave covering an area of 1,499 ha. For most elites, it is a significant loss because the enclave juts into Indonesian territory and leaves only 700 meters from Temajuk Beach. While the settlement of national borders in Gosong Niger needs more attention, considering that Malaysia still often tries to do effective occupation in the region. Although it cannot be used as a baseline, Gosong Niger is still an essential area for Indonesia.

The practice of border diplomacy organized by Indonesia is still state-centric. The management of state demarcation is still limited, which just abandons several important actors in border diplomacy. As a result, non-transparency and misinformation frequently color the Indonesian-Malaysian border talks in Tanjung Datu (the Gamar Bulan and Gosong Niger issues). Subnational actors consisting of political elites at the provincial to village level do not directly gain access to the management of state borders. While the Malindo Socio-Economic Coordination Committee, which was organized to manage the Indonesian Malaysian border region on socio-economic issues, was not enough to be a bridge for all information and coordination in border management.

In addition to subnational actors, who are also referred to as paradiplomacy by some academics, there are important actors in the issue of the Malaysian-Malaysian border, namely academics. Limited information on the management of the border area has resulted in inaccuracies in the mention and provision of data in several academic studies. It is certainly not clear enough reference for those who access the results of the study. Border diplomacy should no longer be state-centric for the sake of establishing harmonious bilateral relations between neighboring countries by involving some extraordinary deeds, subnational actors, academics, and the media.

\section{ACKNOWLEDGMENT}

This article is part of the PTUPT research of the Ministry of Research and Higher Education of the Republic of Indonesia, for that we express our gratitude for the opportunity and support provided to us so that this research on Indonesian border diplomacy could be carried out. We would also like to thank the LPPM UPN "Veteran" Yogyakarta for providing facilities and support during the research.

\section{REFERENCE}

Andika, M. T. (2017). Indonesia Border Diplomacy Under the Global Maritime Fulcrum. Ritsumeikan International Affairs, $15,45-46$

Anggita, M. (2014). Kesepakatan Batas Darat Ri-Timor Leste: Sebuah Kajian Diplomasi Perbatasan RI. Jurnal Penelitian Politik, 11 (1), 21-38.

Aranda, G., \& Salinas, S. (2017). Paradiplomacia Aymara: Empoderamiento En La Frontera [Aymara Paradiplomacy: Empowerment On The Border]. Estudios Fronterizos, 18 (35), 90-106. doi:10.21670/ref.2017.35.a05

Arsana, I. M. A. (2006). "Gosong Niger: Is it Another Ambalat?" http://geo-boundaries. blogspot.com/2006/03/gosong-ni ger-is-it-another-ambalat.html

Baylis, J., \& Smith, S. (2001). The Globalization of World Politics New York: Oxford University Press.

Bennet, Fred. (1996). A Liberal Theory of Borders. National Library of Canada. 
Biro Komunikasi dan Informasi Publik. (2015). Menara Mercusuar Tanjung Datu, Mercusuar Terjauh di Kalimantan Barat. Retrieved June 26, 2019, from http://dephub. go.id/post/read/menara-mercusuar-tanjung-datu,-mercusu ar-terjauh-di-kalimantan-barat

Bradshaw, M. J. (1998). Going global: The Political Economy of Oil and Gas Development Offshore of Sakhalin. Cambridge Review of International Affairs, 12(1).

Caflish, L. (2000). A typology of Border. Retrieved June 26, 2019, from www.dur.ac.uk/resources/ibru/ conferences/thailand/ caflisch.pdf.

Chitty, N. (2011). Public Diplomacy: Courting Publics For Short-Term Advantage Or Partnering Publics For Lasting Peace And Sustainable Prosperity?. Diplomatic Studies, 6.

Cornago, N. (2009). Diplomacy And Paradiplomacy In The Redefinition Of International Security: Dimensions Of Conflict And Co-Operation. Regional \& Federal Studies, 9(1), 40-57. doi: 10.1080/13597569908421070

Djalal, H. (2012). Maritime Border Diplomacy. Center for Oceans Law and Policy, 16.

Duchacek, I. (1990). Perforated Sovereignties: Towards a Typology of New Actors in International Relations. In Hans J. Michelmann \& Panayotis Soldatos (eds.), Federalism and International Relations: The Role of Subnational Units. Oxford: Oxford Press.

Fatmasari, M. (2018). Masalah Tanjung Datu. Retrieved June 26, 2019, from http://repository.unpas.ac.id/33730/7/ BAB\%20III.pdf.

The Geographer. (1965). Indonesia - Malaysia Boundary. Retrieved June 26, 2019, from https://fall.fsulawrc.com/collection/Lim itsinSeas/IBS045.pdf.

Gultom, A. (2011). TB Hasanuddin: Klaim Malaysia di Camar Bulan dan Tanjung Datu Tidak Sesuai Peta Tua. Retrieved July 3, 2019, from https://rmol.co/dpr/read/2011/10/09/41852/.

Hadiwijoyo, S. S. (2011). Perbatasan Negara dalam Dimensi Hukum Internasional. Yogyakarta: Graha Ilmu.

Henrikson, A. K. (2000). Facing Across Borders: The Diplomacy of BonVoisinage. International Political Science Review, 21(2), 121-147.

Himmrich, Julia (2016). Bringing Academics Closer to Foreign Policy. Retrieved June 26, 2019, from https://ww w.stiftung-mercator.de/media/downloads/3_Publiktionen/ Himmrich_Julia_Dahrendorf_Analysis-Bringing-Academ ics-Closer-to-Foreign-Policy.pdf.

Huijgh, Ellen. (2016). The Public Diplomacy of Emerging Powers part2: The Case of Indonesia. Figueroa Press: Los Angeles.

Ion, Georgeta., Iftimescu, S., Proteasa, C., \& Marin, E. (2019). Understanding the Role, Expectations, and Challenges That Policy-Makers Face in Using Educational Research. Education Sciences Journal, 9(81).

Jayanto, S. D. (2014). Upaya Pemerintah Indonesia Untuk Menyele saikan Konflik Gosong Niger. Journal IImu Hubungan Internasional, 2(3).

Jordan, A., \& Khanna, J. (1995). Economic Interdependence and Challenges to the Nation-State: The Emergence of Natural Economic Territories in the Asia-Pacific. International Journal of International Affairs, 48

Kalbariana. (2011). Pulau Gosong: Hilang Patok Di Ekor Kaliman tan. Retrieved June 26, 2019, from https://www.kalbaria
na.web.id/pulau-gosong-hilang-patok-di-ekor-kalimantan/K.

Kireev, A. (2015). State Border. In Sergei V., Jussi P. L., \& Anton, A. (eds.). Introduction to Border Studies. Dalnauka Vladiv ostok. Far Eastern Federal University.

La Porte, T. (2012). The Impact of 'Intermestic' Non-State Actors on the Conceptual Framework of Public Diplomacy. The Hague Journal of Diplomacy, 7, 441-458.

Martínez, Z. R. (2018). The Paradiplomacy of Subnational Govern ments In North America. Ánfora, 25(44), 17-41.

Muluk, K., \& Winoto, S. (2018). Role Of Research/Academic In Policy Formulation. Journal Of Applied Management Volume, 16(2), 285-292.

Mursito, P. (2010). Peran Arsip Dalam Mendukung Upaya Diplomasi Guna Penyelesaian Sengketa Perbatasan Camar Bulan Dan Tanjung Datu. Jurnal Kearsipan, 7(12).

Oegroseno, A. H. (2006). Makalah: Kebijakan Dasar Indonesia Dalam Penetapan Perbatasan Maritim. Departemen Luar Negeri RI. Makalah pada Penataran Singkat Pengembangan Bahan Ajar Hukum Internasional, Fakultas Hukum Universi tas Diponegoro, Semarang, 6-8 Juni 2006.

Palupi, F. (2007). Eksistensi Garis Batas Landas Kontinen Antara Indonesia dan Malaysia Di Gosong Niger Ditinjau Dari Hukum Laut Internasional. Retrieved June 26, 2019, from https://eprints.uns.ac.id/4005/1/5540090620090957.

Paasi, A. (2009). Political Boundaries. In Kitchin, R., \& N, Thrift (eds.) International Encyclopedia in Human Geography. Elsevier: London.

Rachmawati, I., \& Fauzan. (2012). Problem Diplomasi Perbatasan dalam Tata Kelola Perbatasan Indonesia-Malaysia. Jurnal Ilmu Sosial dan Politik,16(2).

Rachmawati, I., \& dan Dewi, M. A. (2019). Temajuk: Pesona Dan Masalah Di Batas Negeri. Yogyakarta: LPPM UPNYK Press.

Rachmawati, I., \& and Dewi, M. A. (2020). Rethinking of Indonesia Border Diplomacy. Proceeding of International Conference Arts, Education and Social Science (ICAES), Moscow, Russian Federation on 10 - 11 April 2020.

Republika. (2014). RI Desak Malaysia Hentikan Pembangunan. Retrieved July 3, 2019, from https://www.republika. co.id/berita/koran/kesra/14/05/26/n60t2312-ri-desak-malay sia-hentikan-pembangunan

Roy, S. L. (1995). Diplomasi. Jakarta: Rajawali Press.

Sergounin, A. (1999). The Bright side of Russia's Regionalism. Retrieved July 3, 2019, from http://www.fas.har vard.edu/ ponars/POLICY\%20MEMOS/Sergounin59.html.

Starke, J. G. (1972). An Introduction to International Law. Butterworths

Sucipto. (2014). Malaysia Bangun Mercusuar di Wilayah Sengketa, TNI Kirim Kapal Perang. Sindonews.com. Retrieved July 3, 2019, from https://nasional.sindone ws.com/read/865962/14/malaysia-bangun-mercusu ar-di-wilayah-sengkta-tni-kirim-kapal-perang-1400680494.

Syahni, M. (2014). Indonesia-Malaysia Akan Bertemu Bahas Koordinat Mercusuar di Tanjung Datuk. Kompas.com. Retrieved September 13, 2019, from https://nasional.kom pas.com/read/2014/06/16/1527212/Indonesia-Malay sia.Akan.Bertemu.Bahas.Koordinat.Mercusuar.di.Tanjung. Datuk.

Viva. (2014). Mercusuar Malaysia di Perairan Indonesia. Viva.co.id. Retrieved June 27, 2019, from https://www.viva. 
14. JURNAL HUBUNGAN INTERNASIONAL

VOL. 9, NO. 1 (2020): April-September 2020

co.id/berita/nasional/508381-foto-ini-mercusuar-malay sia-di-perairan-indonesia

Wirawan, M. R. (2019). Peran Paradiplomasi dalam Kerjasama Antar Negara: Studi Kasus Kerjasama Indonesia-Malaysia dalam Mengelola Kawasan Perbatasan di Sambas.

Yogyakarta: Universitas Pembangunan Nasional 'Veteran' Yogyakarta (unpublished) 